\title{
Anti-Amyloidogenic and Cyclooxygenase Inhibitory Activity of Guettarda speciosa
}

\author{
Mario A. Tan $1,2,3,4, *$, Mark Wilson D. Lagamayo ${ }^{2}$, Grecebio Jonathan D. Alejandro ${ }^{2,3,4}$ \\ and Seong Soo A. An ${ }^{1, *}$ \\ 1 Department of Bionano Technology, Bionano Research Institute, Gachon University, 1342 Sungnam-daero, \\ Sujung-gu, Seongnam-si, Gyeonggi-do 461-701, Korea \\ 2 Graduate School, University of Santo Tomas, Manila 1015, Philippines; \\ mwdlagamayo@gmail.com (M.W.D.L.); gdalejandro@ust.edu.ph (G.J.D.A.) \\ 3 Research Center for the Natural and Applied Sciences, University of Santo Tomas, Manila 1015, Philippines \\ 4 College of Science, University of Santo Tomas, Manila 1015, Philippines \\ * Correspondence: matan@ust.edu.ph (M.A.T.); seong.an@gmail.com (S.S.A.A.); Tel.: +63-2-7314031 (M.A.T.); \\ $+82-31-750-8755$ (S.S.A.A) \\ Academic Editors: Raffaele Capasso, Lorenzo Di Cesare Mannelli and Nicola Volpi \\ Received: 23 September 2019; Accepted: 11 November 2019; Published: 14 November 2019

\begin{abstract}
Guettarda speciosa is known in traditional folk medicine for treating cough, cold, sore throat, fever, wounds, epilepsy, and headaches. To discover the scientific pharmacological potential of G. speciosa, we explore its anti-inflammatory, cytotoxicity, and inhibition of amyloid-beta (A $\beta$ ) aggregation effects. Cyclooxygenase assay of the G. speciosa $\mathrm{CHCl}_{3}$ (GSC) extract and G. speciosa $\mathrm{MeOH}$ (GSM) extract are more selective to COX-1 inhibition with a $50 \%$ inhibitory concentration $\left(\mathrm{IC}_{50}\right)$ of $3.56 \mu \mathrm{g} / \mathrm{mL}$ for the GSC extract and $4.98 \mu \mathrm{g} / \mathrm{mL}$ for the GSM extract. Neuroblastoma SH-SY5Y inhibition and thioflavin T assay amyloid-beta (A $\beta$ ) aggregate inhibition of the GSM and GSC extracts showed their potential therapeutic effects against Alzheimer's disease. The putative compounds from the LC-MS analysis could be responsible for the observed activities. The results suggest that G. speciosa possesses anti-inflammatory and anti-neurodegenerative properties and a promising lead as a source of pharmacologically active compounds.
\end{abstract}

Keywords: Alzheimer's disease; COX-1; cytotoxicity; Guettarda speciosa; thioflavin T

\section{Introduction}

Guettarda speciosa L. (Rubiaceae) is a perennial shrub or small tree, which grows in coastal habitats in tropical areas. This species is the only representative of the genus Guettarda L. in the Philippines [1]. The genus is widely distributed from East Africa to South and Southeast Asia and the South Pacific [2]. It is regarded as a medicinal plant used in traditional folk medicine for treating postpartum infection, cough, cold, sore throat, dysentery, fever, boils, wounds, epilepsy, and headache [3-6]. In African medicinal plants, the flower decoction was combined with Ocimum americanum L. and O. gratissimum L. to treat malaria, while the roots are used for diarrhea (decoction), rheumatism (rubdown on articulations), and pelvic pain (massage) [7]. These traditional folkloric claims were corroborated by pharmacological studies including the antiepileptic activity of the inner bark extract from India [5] and the anti-inflammatory activity in murine macrophages of the methanolic extract from Indonesia [8]. Phytochemical analysis has elaborated the presence of iridoids and their glucosides, phenolics, glycerol derivatives, steroids, triterpenoids [9,10], and fatty acids [11]. There is limited information on the biological activities and chemical constituents associated with G. speciosa.

To address this gap, and in the interest of searching for medicinal Rubiaceae plants from the Philippines with potential anti-inflammatory and anti-neurodegenerative activities [12-15], we herein 
describe the acute toxicity, cyclooxygenase inhibition, and anti-amyloidogenic activity of the extracts of G. speciosa.

\section{Results}

\subsection{Acute Oral Toxicity}

No death was observed among the animals over the 14-day period. Hence, assessment of the acute oral toxicity indicated that the G. speciosa $\mathrm{MeOH}$ (GSM) extract was safe and nontoxic up to $2000 \mathrm{mg} / \mathrm{kg}$ following the Organization for Economic Co-operation and Development (OECD) 425 guidelines. Prominent signs of toxicity and abnormalities were also not observed. Moreover, the post toxicity and gross necropsy study showed that all vital organs, such as the liver, kidneys, and stomach, were comparable to the control group as indicated in the histopathological results (Figure 1) analyzed by a licensed veterinarian.

\section{Normal Individual}
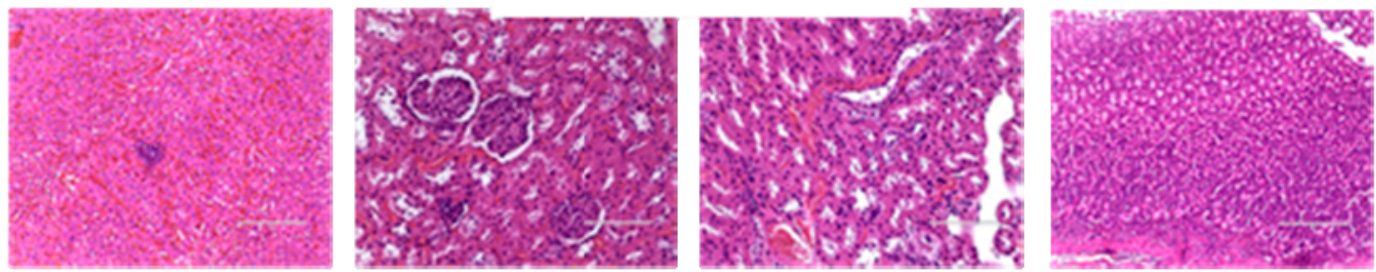

Treated Group

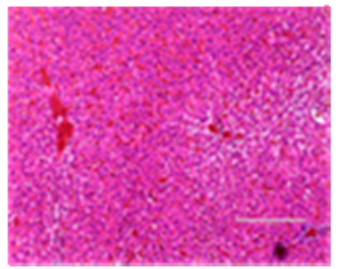

(a)

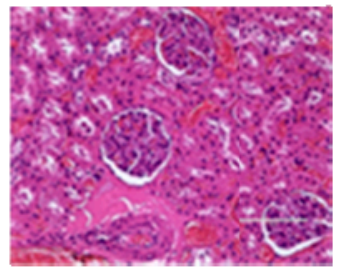

(b)

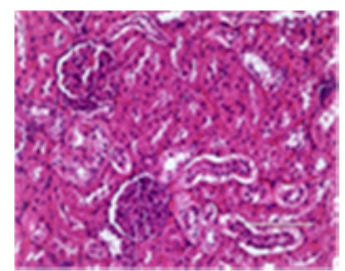

(c)

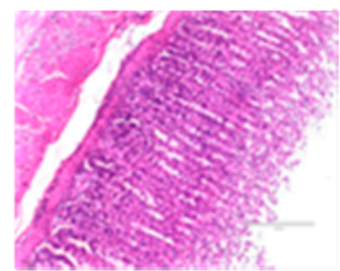

(d)

Figure 1. Histopathological examination of (a) liver, (b) left kidney, (c) right kidney, and (d) stomach in normal and G. speciosa extract-treated (GSM) groups. No significant changes were observed in the examined vital organs of the GSM-treated groups when compared to the normal control group.

\subsection{COX-1 and COX-2 Assay}

Aerial parts of G. speciosa were extracted with $\mathrm{MeOH}$ to afford the crude extract (GSM).Various extracts of G. speciosa with varying polarity were prepared using solvent partitioning. Nonpolar compounds are contained in the G. speciosa hexane (GSH) extract, semi-polar compounds in the G. speciosa $\mathrm{CHCl}_{3}$ (GSC) extract, and polar compounds in the G. speciosa aqueous (GSA) extract. All the extracts were dried free of solvents prior to use in the succeeding experiments.

The cyclooxygenase screening assay results of the G. speciosa extracts (Figure 2) showed a greater inhibition to the COX-1 enzyme as compared to the COX-2. The extracts were initially tested at a concentration of $10 \mu \mathrm{g} / \mathrm{mL}$. More than $50 \%$ inhibition for the COX-1 enzyme was observed for GSC $(66.68 \% \pm 2.77)$ and GSM $(62.25 \% \pm 2.39)$ extracts. None of the extracts gave a $50 \%$ inhibition using COX-2 enzyme with the GSC extract exhibiting the highest inhibition with $30.85 \% \pm 5.11$. Interestingly, the GSM extract exhibited a negative inhibition with COX-2 $(-9.98 \% \pm 5.62)$. The percentage inhibition of the extracts had a significant difference when compared to the positive control, indomethacin $(4.0 \mathrm{mM})(85.1-86.3 \%)$, at $p<0.05$. 


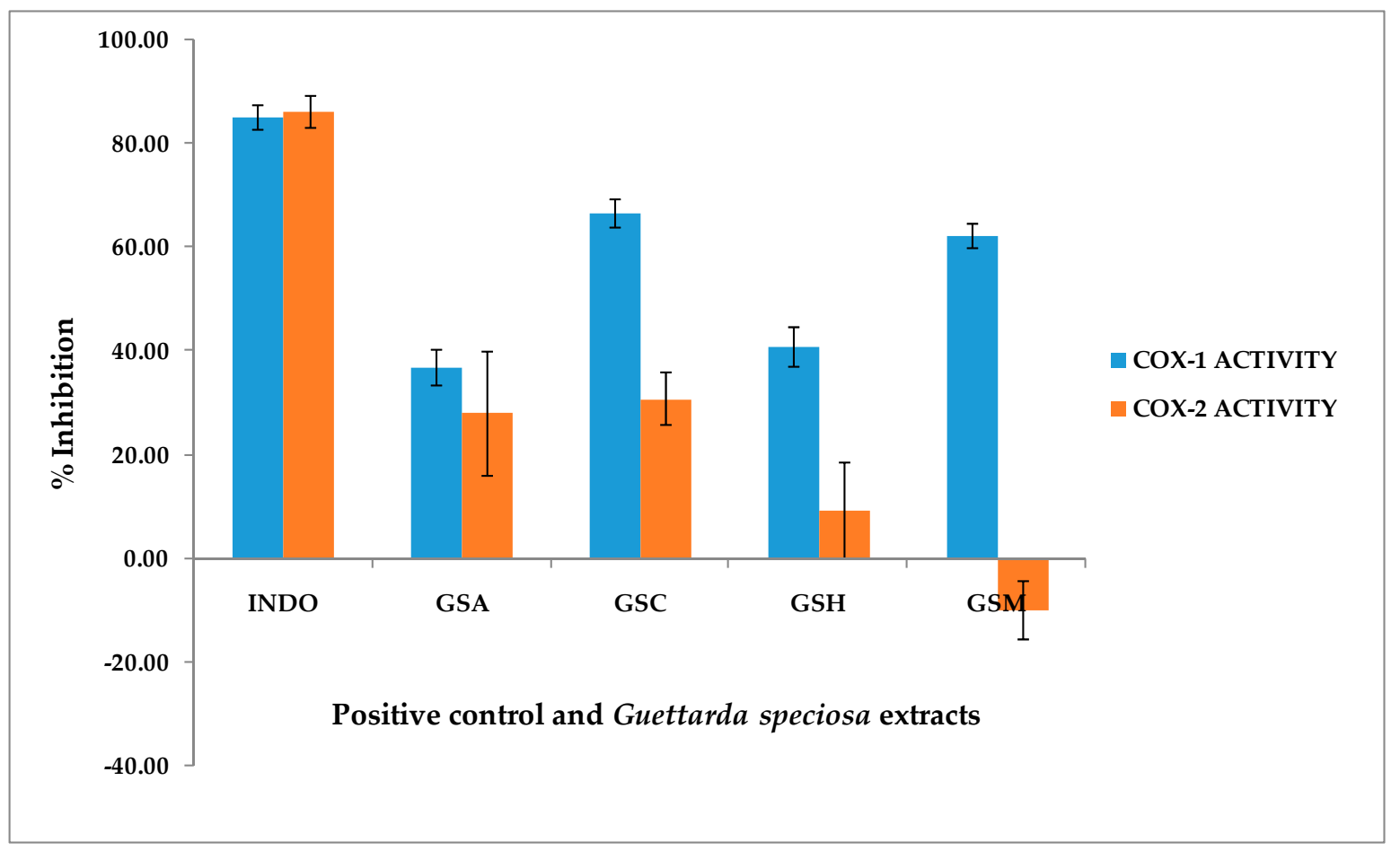

Figure 2. In vitro cyclooxygenase screening of Guettarda speciosa (G. speciosa) extracts at a concentration of $10 \mu \mathrm{g} / \mathrm{mL}$. The G. speciosa extracts exhibited an inhibition to the COX-1 enzyme with the chloroform GSC and methanol GSM extracts showing a greater than 50\% inhibition. Indomethacin (4.0 $\mathrm{mM})$ (INDO) was used as the positive control. GSA-G. speciosa aqueous extract; GSC—G. speciosa $\mathrm{CHCl}_{3}$ extract; GSH—G. speciosa hexane extract; GSM-G. speciosa MeOH extract.

Based on the screening results, the $50 \%$ inhibitive concentration $\left(\mathrm{IC}_{50}\right)$ of the GSC and GSM extracts for COX-1 were also determined using seven concentrations $(0.5,1,5,10,40,70$, and $100 \mu \mathrm{g} / \mathrm{mL})$. The results indicate an $\mathrm{IC}_{50}$ of $3.56 \mu \mathrm{g} / \mathrm{mL}$ for the GSC extract and $4.98 \mu \mathrm{g} / \mathrm{mL}$ for the GSM extract. Because of the promising results in the cyclooxygenase assay, the GSM and GSC extracts were further evaluated via cell viability and thioflavin $\mathrm{T}$ assays.

\subsection{Cell Viability}

The cytotoxicity of the GSM and GSC extracts was explored against neuroblastoma SH-SY5Y utilizing the ATP luminescence assay. The ATP serves as the cell's most important chemical energy storage for all biological processes. When cells are exposed to environmental or metabolic stressors (depleted iron and carbon sources), their ability to produce ATP is impeded. Hence, cellular ATP measurement is a good indication of a cell's metabolic health and subsequent viability. As illustrated in Figure 3, the GSM extract exhibited a 17\% cell growth inhibition using the smallest concentration of $0.39 \mu \mathrm{g} / \mathrm{mL}$, followed by $25 \%$ growth inhibition at $0.78 \mu \mathrm{g} / \mathrm{mL}$. Surprisingly, an almost similar trend was observed, using $12.5,6.25,3.13$, and $1.56 \mu \mathrm{g} / \mathrm{mL}$ concentrations with cell growth inhibitions at $35-38 \%$. The highest concentration at $50 \mu \mathrm{g} / \mathrm{mL}$ showed a cell growth inhibition of $57 \%$. Compared to the negative control, a significant difference was shown on the cell cytotoxicity of the extracts at all the given concentrations $(p<0.05)$. Cytotoxicity was also observed on the GSC extracts in a concentration-dependent manner from 0.39 to $50 \mu \mathrm{g} / \mathrm{mL}$ as observed in Figure 3. A 62\% cell growth inhibition was noted on the $50 \mu \mathrm{g} / \mathrm{mL}$, followed by the $25 \mu \mathrm{g} / \mathrm{mL}$ with $50 \%$ inhibition. The lowest concentration, $0.39 \mu \mathrm{g} / \mathrm{mL}$, showed only a $6 \%$ cell growth inhibition with a cell viability of $94 \%$. Statistical analyses also indicated a significant difference on the percentage cell viability of the GSC extracts when compared to the control (100\% cell viability), with the exception of the lowest concentration $(0.39 \mu \mathrm{g} / \mathrm{mL})$. 


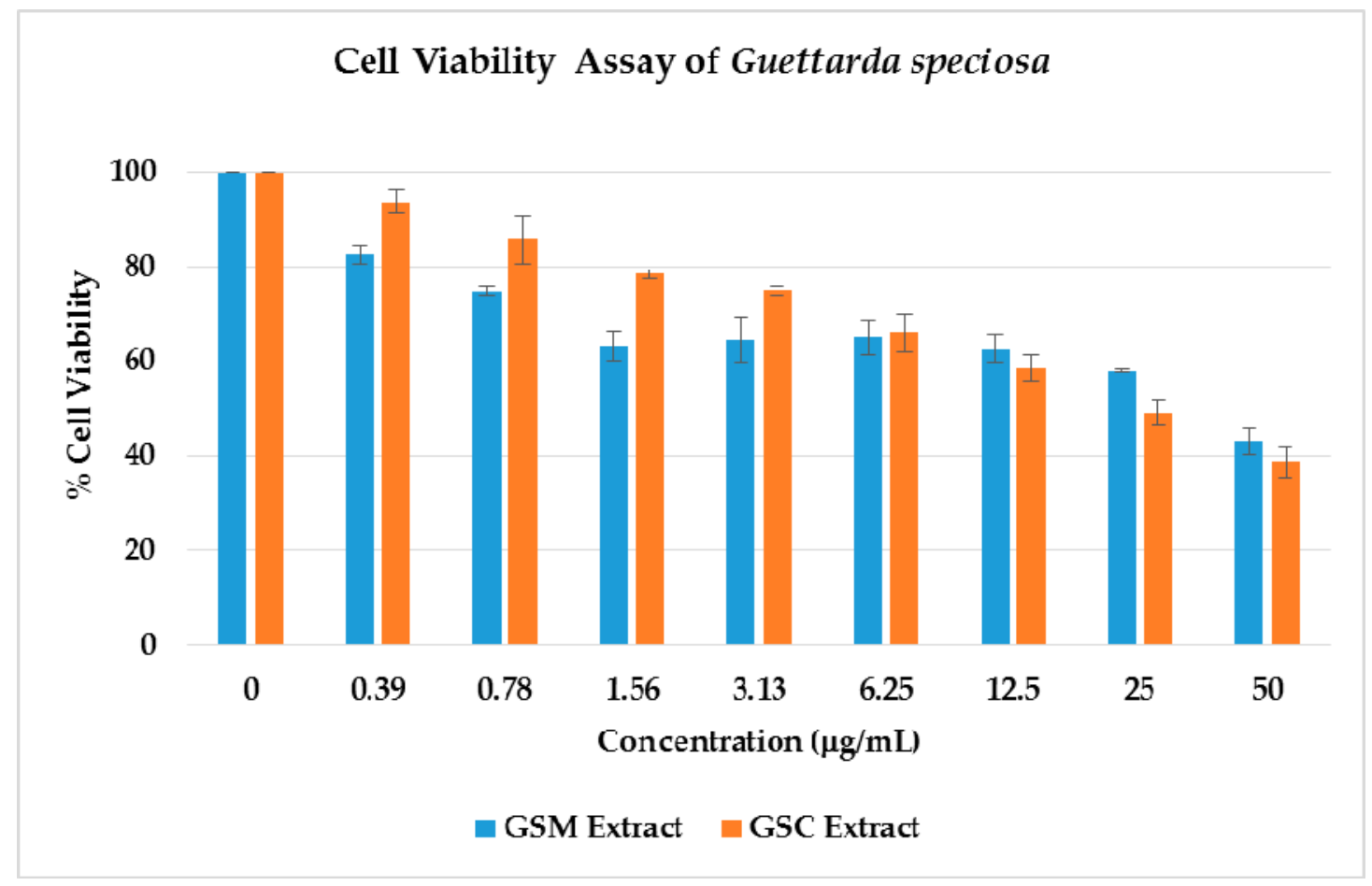

Figure 3. Effect of Guettarda speciosa $\mathrm{MeOH}$ (GSM) and $\mathrm{CHCl}_{3}$ (GSC) extracts on cell viability in neuroblastoma SH-SY5Y cells. Cell viability was determined using the ATP luminescence assay. The results indicate $\%$ cell viability vs. the negative control (mean \pm SD of triplicate measurement). All of the extracts exhibited a significant difference on the \% cell viability on the negative control vs. the plant extracts at $p<0.05$, except for the GSC extract at $0.39 \mu \mathrm{g} / \mathrm{mL}$ ).

Through the cell viability ATP luminescence assay, the half maximal inhibitory concentration of the cell population death was determined. The GSM extract inhibited the growth of SH-SY5Y cells with an $\mathrm{IC}_{50}$ value of $43.44 \mu \mathrm{g} / \mathrm{mL}$. The GSC extract was found to be more active with an $\mathrm{IC}_{50}$ of 8.049 $\mu \mathrm{g} / \mathrm{mL}$. SH-SY5Y cells have been used in many neurological studies, such as Parkinson's disease (PD), Alzheimer's disease (AD), and traumatic brain injury (TBI) [16]. The cell viability of the neuroblastoma SH-SY5Y cells against the GSM extracts may suggest promising leads with respect to the identification of potential bioactive secondary metabolites in neurological diseases.

\subsection{Thioflavin T (ThT) Assay}

The abnormal aggregation of $\beta$-amyloid $(A \beta)$, tau protein accumulation, decreased acetylcholine, oxidative stress, and neuroinflammation of the nervous system are some of the pathological hallmarks associated with Alzheimer's disease. To address whether the GSM and GSC extracts are capable of inhibiting the aggregation of $A \beta$, we also utilized thioflavin $T$ (ThT) assay using phenol red as the positive control (Table 1). The GSC extract at $50 \mu \mathrm{g} / \mathrm{mL}$ exhibited the highest inhibition of the A $\beta$ fibril formation with $65.78 \%$. This is also statistically comparable $(p<0.05)$ to the inhibition of the positive control at $69.85 \%$. The GSM extract gave a $54.71 \%$ inhibition but is statistically different from the positive control $(p<0.05)$. The observed activity of the GSC and GSM extracts may be attributed to the presence of secondary metabolites, which could be capable of inhibiting the $A \beta$ fibril formation. 
Table 1. Thioflavin T (ThT) assay results of Guettarda speciosa extracts.

\begin{tabular}{cc}
\hline & $\mathbf{A} \boldsymbol{\beta}_{\mathbf{1 - 4 2}}$ \\
\hline & Aggregation Inhibition (\%) ${ }^{\mathbf{a}}$ \\
\hline Phenol Red $(50 \mu \mathrm{M})^{\mathrm{b}}$ & $69.85 \pm 0.29$ \\
GSM Extract $(50 \mu \mathrm{g} / \mathrm{mL})$ & $54.71 \pm 2.92$ \\
GSM Extract $(5 \mu \mathrm{g} / \mathrm{mL})$ & $17.20 \pm 0.85$ \\
GSC Extract $(50 \mu \mathrm{g} / \mathrm{mL})$ & $65.78 \pm 3.12^{*}$ \\
GSC Extract $(5 \mu \mathrm{g} / \mathrm{mL})$ & $24.63 \pm 1.19$ \\
\hline
\end{tabular}

a The values are expressed as mean \pm SD of three trial experiments. ${ }^{b}$ The positive control. ${ }^{*}$ No significant difference with the positive control at $p<0.05$. GSM-G. speciosa MeOH extract; GSC-G. speciosa $\mathrm{CHCl}_{3}$ extract.

\subsection{Metabolite Profiling}

A total of nine putatively identified compounds were determined from the GSM extract using LC-MS analysis. Optimized run method produced the LC chromatogram as shown in Figure 4, where the $\mathrm{Y}$-axis represents the $\%$ signal intensity and the $\mathrm{X}$-axis is the retention time in minutes. The compounds presented (Table 2 and Figure 5) are those that fall within the "good match" standards of the Traditional Chinese Medicine (TCM) library $[17,18]$. These putatively identified nine compounds were also previously isolated from the different Guettarda species based on the available literature data. Loganin (3) was isolated from G. platypoda DC. [19] and G. pohliana Müll. Arg. [20]; rotundic acid (7) from G. angelica Mart. ex Müll. Arg. [21] and G. platypoda [22]; quinovic acid (9) from G. angelica [23] and G. platypoda [22,24]; strictosidine (1), sickingine (5), 5-caffeoylquinic acid (6), and 4,5-dicaffeoylquinic acid (8) from G. acreana K. Krause [3]; sweroside (2) from G. platypoda [24] and G. pohliana [20]; and $\beta$-sitosterol (4) from G. platypoda [22]. Interestingly, the putatively identified compounds exhibit diverse biological activities as reported in the literature (Table 2). The putatively identified metabolites with their reported activities in the literature may explain the biological activities exhibited by the extracts in this study. Several compounds were identified to have anti-inflammatory activity $(2,4$, and $\mathbf{6})$, cytotoxicity ( 2 and 3$)$, and neuroprotective (3) activity.

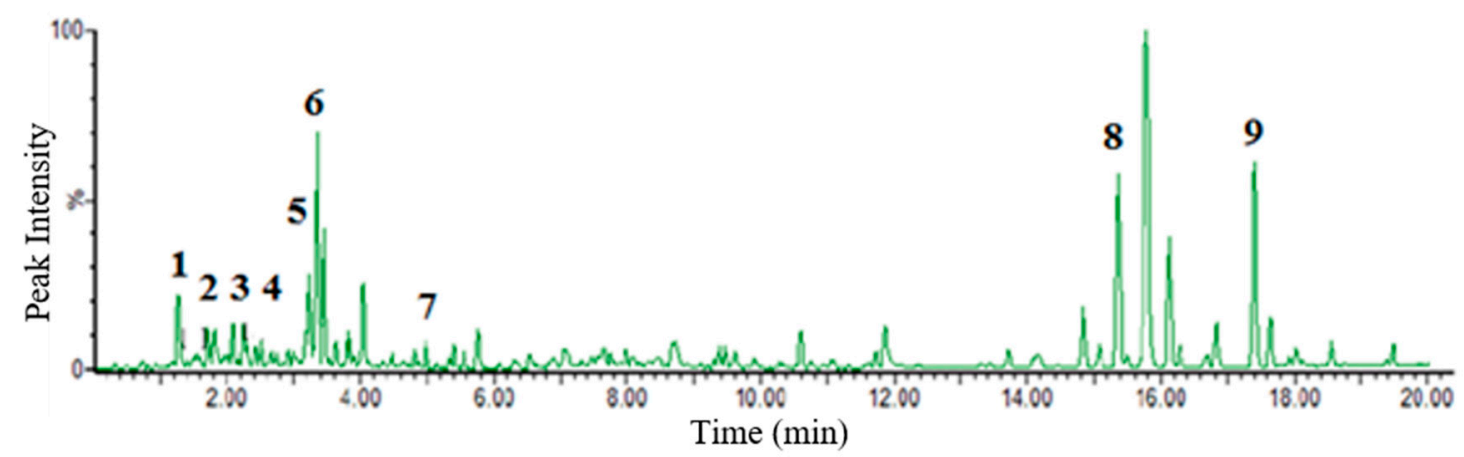

Figure 4. Chromatogram of G. speciosa $\mathrm{MeOH}$ (GSM) extract. Nine putative compounds were identified utilizing the UNIFI data analysis software and comparing the acquired MS spectra to library matching using the Traditional Chinese Medicine (TCM) library that is incorporated in the UNIFI analysis software. All of these compounds were previously isolated from other Guettarda species. The x-axis is the retention time in minutes, while the $y$-axis is the peak \% signal intensity. 
Table 2. LC-MS putative compounds from G. speciosa (GSM) extract.

\begin{tabular}{|c|c|c|c|c|c|c|}
\hline \multirow{2}{*}{ RT } & \multicolumn{2}{|c|}{ Exact Mass } & \multirow{2}{*}{$\begin{array}{l}\text { Elemental } \\
\text { Composition }\end{array}$} & \multirow{2}{*}{$\begin{array}{l}\text { Error } \\
(\mathrm{ppm})\end{array}$} & \multirow{2}{*}{ Putative Identity } & \multirow{2}{*}{ Biological Activity } \\
\hline & Calculated & Observed & & & & \\
\hline 1.27 & 530.22644 & 530.22500 & $\mathrm{C}_{27} \mathrm{H}_{34} \mathrm{~N}_{2} \mathrm{O}_{9}$ & -2.63 & Strictosidine (1) & Antimicrobial [25] \\
\hline 2.26 & 358.12638 & 358.12690 & $\mathrm{C}_{16} \mathrm{H}_{22} \mathrm{O}_{9}$ & 1.45 & Sweroside (2) & $\begin{array}{c}\text { Cytotoxic [26]; } \\
\text { Antigenotoxic [27]; } \\
\text { Antiosteoporotic [28]; } \\
\text { Anti-inflammatory [29] }\end{array}$ \\
\hline 2.35 & 390.15259 & 390.15900 & $\mathrm{C}_{17} \mathrm{H}_{26} \mathrm{O}_{10}$ & 2.35 & Loganin (3) & $\begin{array}{l}\text { Antigenotoxic [27]; } \\
\text { Neuroprotective [30]; } \\
\text { Cytotoxic [31] }\end{array}$ \\
\hline 2.42 & 414.38617 & 414.38650 & $\mathrm{C}_{29} \mathrm{H}_{50} \mathrm{O}$ & 0.72 & $\beta$-Sitosterol (4) & $\begin{array}{c}\text { Anti-inflammatory [32,33]; } \\
\text { Antipyretic [33] Anthelminthic, } \\
\text { Antimutagenic, Analgesic [34] }\end{array}$ \\
\hline 3.25 & 528.21100 & 528.21050 & $\mathrm{C}_{27} \mathrm{H}_{32} \mathrm{~N}_{2} \mathrm{O}_{9}$ & -0.94 & Sickingine (5) & \\
\hline 3.37 & 354.09509 & 354.09430 & $\mathrm{C}_{16} \mathrm{H}_{18} \mathrm{O}_{9}$ & -2.25 & $\begin{array}{l}\text { 5-Caffeoylquinic } \\
\text { acid (6) }\end{array}$ & $\begin{array}{c}\text { Antimicrobial [35] } \\
\text { Anti-inflammatory [36] }\end{array}$ \\
\hline 4.93 & 488.35019 & 488.35210 & $\mathrm{C}_{30} \mathrm{H}_{48} \mathrm{O}_{5}$ & 3.88 & Rotundic acid (7) & Antimicrobial $[37,38]$ \\
\hline 15.37 & 516.45500 & 516.45460 & $\mathrm{C}_{25} \mathrm{H}_{24} \mathrm{O}_{12}$ & -0.77 & $\begin{array}{l}\text { 4,5-Dicaffeoylquinic } \\
\text { acid (8) }\end{array}$ & Antipigmentation [39] \\
\hline 17.35 & 486.33453 & 486.33290 & $\mathrm{C}_{30} \mathrm{H}_{46} \mathrm{O}_{5}$ & -3.28 & Quinovic acid (9) & \\
\hline
\end{tabular}

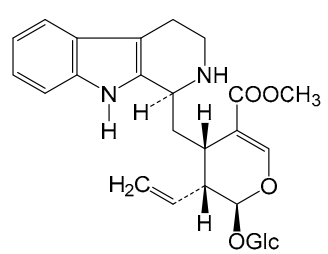

Strictosidine (1)<smiles>C=CC1C(OC)OC=C2C(=O)OCCC21</smiles>

Sweroside (2)

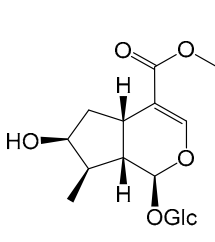

Loganin (3)

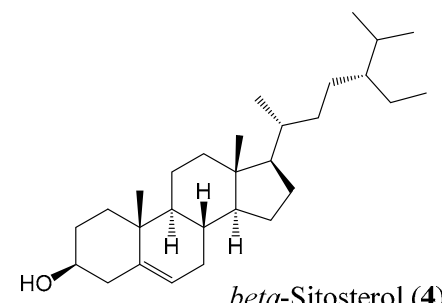

beta-Sitosterol (4)<smiles>O=C1OCC(O)(C(=O)O)C=C1O</smiles>

5-Caffeoylquinic acid (6) $\mathrm{R}=$ caffeoyl $\quad \mathrm{R}_{1}=\mathrm{H}$<smiles>C=C[C@H]1[C@H](OC(C)=O)OC=C2CN3C(C(=O)O)Cc4c([nH]c5ccccc45)[C@H]3C[C@H]21</smiles>

Sickingine (5)

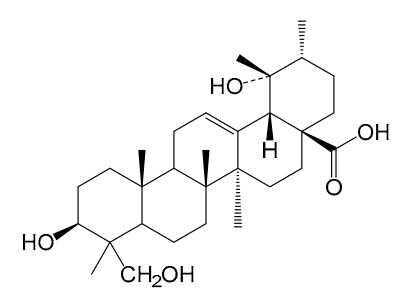

Rotundic acid (7)<smiles>CCOC(O)C1CCCCC1C(=O)O</smiles>

4,5-Dicaffeoylquinic acid (8) $\mathrm{R}=\mathrm{R} 1=$ caffeoyl

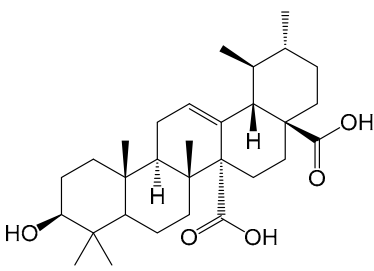

Quinovic acid (9)

Figure 5. Structures of putatively identified compounds from G. speciosa.

\section{Discussion.}

In our continuous study using endemic Rubiaceae species indigenous to the Philippines, we described the potential therapeutic effects of G. speciosa extracts. The leaf extracts of G. speciosa, free from any trace of solvents, have been shown to inhibit in vitro the aggregation of $A \beta_{1-42}$, cyclooxygenase-1 enzyme, and cell growth of neuroblastoma SH-SY5Y cells. These biological activities may be ascribed to the compounds that were characterized using untargeted LC-MS. Natural products from plants continue to be the source of pharmacologically active compounds with diverse structures in the treatment or prevention of various diseases. In this experiment, these compounds were defined as indole alkaloids $(\mathbf{1}, 5)$, iridoids $(2,3)$, steroid $(4)$, triterpenoids $(7,9)$, and polyhydroxy cyclic acids $(6,8)$. Pharmacological studies on G. platypoda have reported the synergistic action of quinic acid glycosides with $\beta$-sitosterol and triterpenes with anti-inflammatory activity, while the mechanism 
of $\beta$-sitosterol is comparable to hydrocortisone [32]. Most of the Rubiaceae species also contained iridoids and indole alkaloids [40], which are known to possess anti-inflammatory activities [41,42].

This study also described the inclination of the G. speciosa extracts to COX-1 inhibition as compared to the COX-2 enzyme. Both COX-1 and COX-2 perform a complex function in the mechanism of central nervous system (CNS) inflammation [43]. Most studies prefer a COX-2 inhibition, because COX-1 is involved in the cytoprotective function in the gastrointestinal system. Moreover, the suppression of COX-1 can result in side effects, including ulcers and bleeding [44]. Several studies have reconsidered the advantages of selective COX-1 inhibition. As stated, COX-1-dependent prostaglandin synthesis is implicated in pathological progressions, including atherosclerosis, cancer, endothelial dysfunction, neuroinflammation, preterm labor, and pain $[43,45]$.

Alzheimer's disease (AD) is the most common cause of neurodegenerative dementia in elderly people, often associated witha progressive memory loss and other cognitive impairments [12]. Abnormal $\beta$-amyloid (A $\beta$ ) deposition, tau protein aggregation, a decreased level of acetylcholine, oxidative stress, and neuroinflammation of the nervous system are numerous causes associated with enhanced AD progression [46]. Although there is no cure for AD, currently, only five compounds (donezipil, tacrine, rivastigmine, galantamine, and memantine) are available and approved in the market to reduce the symptoms associated with AD [47]. The biological activity of the GSM extracts to inhibit the $\mathrm{A} \beta$ aggregation exhibits the potential of this medicinal plant as a new pharmacologicallyactive material or therapeutic agent to minimize the effect of AD. To the best of our knowledge, this is the first report on the SH-SY5Y cytotoxicity, A $\beta$ aggregation prevention, and COX-1 inhibition activities associated with G. speciosa.

\section{Materials and Methods}

\subsection{PlantMaterials}

Fresh leaves of G. speciosa were collected from Bantayan Island, Cebu, Philippines (11 $12^{\circ} 60.00^{\prime \prime} \mathrm{N}$, $123^{\circ} 43^{\prime} 59.99^{\prime \prime}$ E) in April 2017. The plant was collected and identified by Grecebio Jonathan Alejandro, a Philippine Rubiaceae specialist. A voucher specimen was kept at the University of Santo Tomas Herbarium (USTH 014369).

\subsection{Extraction and Fractionation of Extracts}

Air-dried, ground leaves of G. speciosa $(1.7 \mathrm{~kg})$ were placed in a percolator and extracted with $\mathrm{MeOH}$. The ground leaves were allowed to soak overnight. The extract was drained, collected, and concentrated under reduced pressure using a rotary evaporator. A total of $15.0 \mathrm{~L} \mathrm{MeOH}$ was used with the extraction process repeated thrice. The procedure obtained $207 \mathrm{~g}$ of the $\mathrm{MeOH}$ extract (GSM), and a portion $(158 \mathrm{~g})$ was suspended in distilled $\mathrm{H}_{2} \mathrm{O}(300 \mathrm{~mL})$ and partitioned exhaustively with hexane $(2500 \mathrm{~mL})$. The combined hexane layer was dried with anhydrous $\mathrm{Na}_{2} \mathrm{SO}_{4}$ and concentrated under reduced pressure to obtain the hexane extract $(\mathrm{GSH}, 23.2 \mathrm{~g})$. The aqueous layer was partitioned exhaustively with $\mathrm{CHCl}_{3}(2800 \mathrm{~mL})$. The collected $\mathrm{CHCl}_{3}$ layer was dried with anhydrous $\mathrm{Na}_{2} \mathrm{SO}_{4}$ and concentrated under reduced pressure to obtain the $\mathrm{CHCl}_{3}$ extract (GSC, $10.7 \mathrm{~g}$ ). The aqueous layer was freeze-dried using a lyophilizer (Thermo Fisher Scientific, Singapore) to obtain the aqueous extract (GSA, $18.7 \mathrm{~g}$ ).

\subsection{Animal Study}

The experiment protocol (UST-IACUC code number RC2017-890915) was approved by the Institutional Animal Care and Use Committee (IACUC) at the Research Center for Natural and Applied Sciences (RCNAS), University of Santo Tomas (UST), and was further issued by the Philippine Bureau of Animal Industry and Animal Research Permit.

Six female Sprague-Dawley rats were used to assess the acute oral toxicity following the OECD 425 guidelines. The animals were housed in the UST-RCNAS Animal House and acclimatized to 
laboratory conditions for seven days before conducting the experiment. They were fed with standard rodent pellets and given access to clean drinking water. The laboratory conditions were maintained at a temperature of $25 \pm 3{ }^{\circ} \mathrm{C}$, humidity at $60 \pm 4 \%$, and a $12 / 12 \mathrm{~h} \mathrm{light/dark}$ cycle.

\subsection{Acute Oral Toxicity (OECD 425 Guidelines)}

All animals were fasted for $24 \mathrm{~h}$ to determine their actual weight before receiving the crude extract. One rat served as a normal control group and was treated only with water as the vehicle medium. The animals were given $2000 \mathrm{mg} / \mathrm{kg}$ GSM via gastric gavage. The animals were observed periodically for $24 \mathrm{~h}$ for signs of toxicity; thereafter, they were observed daily for 14 days. The animals were then sacrificed by $\mathrm{CO}_{2}$ inhalation. Gross necropsy, observation of gross pathological changes, and microscopic examination of all livers, kidneys, and stomachs of the test animals were performed by a licensed veterinarian.

\subsection{COX-1 and COX-2 Assay}

The cyclooxygenase assay was based on a previous protocol [15] as follows. The following were added to $150 \mu \mathrm{L}$ of $100 \mathrm{mM}$ Tris: $10 \mu \mathrm{L}$ of 10 ppm plant extracts in DMSO, $10 \mu \mathrm{L}$ of $1000 \mu \mathrm{M}$ Hemin, and $10 \mu \mathrm{L}$ of $250 \mathrm{U} / \mathrm{mL}$ COX-2 or COX-1 enzyme (Cayman Chemicals, Singapore). Indomethacin (Sigma Aldrich, St. Louis, MO, USA) was used as the positive control, and DMSO served as the negative control. The mixture was incubated at $25^{\circ} \mathrm{C}$ for $15 \mathrm{~min}$. After incubation, $10 \mu \mathrm{L}$ of $200 \mu \mathrm{M}$ amplex red was added to the mixture. Then, $10 \mu \mathrm{L}$ of $2000 \mu \mathrm{M}$ arachidonic acid (Sigma Aldrich, St. Louis, MO, USA) was added, and the reaction fluorescence absorbance was monitored for 2 min using Varioskan Flash (Thermo Scientific, Waltham, MA, USA) with excitation and emission wavelengths at 535 and $590 \mathrm{~nm}$, respectively. The percent inhibition of the samples and the positive control were determined based on the averaged slope of each replicate using the following formula:

$\%$ Inhibition $=[($ Slope uninhibited - Slope inhibited $) /$ Slope uninhibited $] * 100$.

"Slope uninhibited" is the slope of the line from the fluorescence intensity vs. time plot of the negative control group, and "slope inhibited" is the slope of the line from the fluorescence intensity vs. time plot of the samples/positive control. The method above was also done for the GSM and GSC extracts at different effective well concentrations $(0.5,1,5,10,40,70$, and $100 \mu \mathrm{g} / \mathrm{mL})$ to obtain the $\mathrm{IC}_{50}$ in $\mu \mathrm{g} / \mathrm{mL}$. Three trials consisting of three replicates per trial were done for each concentration of each sample.

\subsection{Cell Viability Assay}

The neuroblastoma cells (SH-SY5Y) were purchased from the American Type Culture Collection (ATCC, Manassas, VA, USA). SH-SY5Y cells were maintained in Dulbecco's modified eagle media (DMEM) supplemented with 10\% fetal bovine serum (FBS), 1\% kanamycin, and 1\% penicillin. Cell cultures were maintained at $37{ }^{\circ} \mathrm{C}$ in $5 \% \mathrm{CO}_{2}$ and passaged once per week. The SH-SY5Y cells were subcultured into a 96-well plate at $2 \times 10^{5}$ cells/well and incubated for $24 \mathrm{~h}$. After incubation, the cells were treated with plant extracts at different concentrations and incubated for another $72 \mathrm{~h}$. The medium was removed, and the wells were washed with phosphate-buffered saline (PBS). Fresh medium $(100 \mu \mathrm{L})$ was added and incubated for another $30 \mathrm{~min}$. After incubation, CellTiter-Glo ${ }^{\circledR}$ luminescent reagent (100 $\mu \mathrm{L}$; Promega, Madison, WI, USA) was added, and the luminescence was measured using a PerkinElmer Victor- $3^{\circledR}$ multi-plate reader (PerkinElmer, Waltham, MA, USA) [48]. The $50 \%$ inhibitive concentrations of the plant extracts were calculated using a nonlinear regression curve fit (GraphPad Prism ver. 6, San Diego, CA, USA). The values representing cell viability were expressed as means \pm standard deviation (SD) of three trial experiments. 


\subsection{Thioflavin T (ThT) Fluorescense Assay}

$\mathrm{A} \beta_{1-42}\left(\right.$ Aggresure $\left.^{\mathrm{TM}}\right)(10 \mu \mathrm{M}, 30 \mu \mathrm{L})$ in PBS (pH 7.4) was incubated with $(20 \mu \mathrm{L})$ or without the tested extracts at $37^{\circ} \mathrm{C}$ for $24 \mathrm{~h}$ in a 384-well plate. Then, $20 \mu \mathrm{L}$ ThT solution $(50 \mu \mathrm{M})$ in glycine- $\mathrm{NaOH}$ buffer ( $\mathrm{pH}$ 9) was added. The fluorescence signal was measured (excitation wavelength, $450 \mathrm{~nm}$; emission wavelength, $510 \mathrm{~nm}$ ) using a PerkinElmer Victor- $3^{\circledR}$ multi-plate reader. The percentage of aggregation inhibition was calculated using the following equation: $\left[\left(1-I_{\mathrm{Fi}} / I_{\mathrm{FC}}\right) * 100 \%\right]$, where $I_{\mathrm{Fi}}$ and $I_{\mathrm{FC}}$ are the fluorescence absorbance with and without the inhibitors, respectively, after subtracting the background fluorescence of the ThT solution [46].

\subsection{Untargeted LC-MS Metabolite Profiling}

Untargeted LC-MS/MS analysis of the GSM extract was performed using a Xevo G2-S Qtof (Waters Corp., Singapore). The separation was achieved using a BEH HSS T3 column $(50 \times 2.1 \mathrm{~mm}$ internal diameter). The system delivered a constant flow of $0.4 \mathrm{~mL} / \mathrm{min}$, and the mobile phase consisted of $5 \%$ $\mathrm{CH}_{3} \mathrm{CN}$ and $0.1 \% \mathrm{HCOOH}$. The injection volume was $1 \mu \mathrm{L}$. For operation in MS/MS mode, a mass spectrometer with an electrospray interface (ESI) was used, and the parameters were set as follows: capillary voltage, $3.0 \mathrm{kV}$ for negative mode; source temperature, $120^{\circ} \mathrm{C}$; desolvation temperature, $400{ }^{\circ} \mathrm{C}$; cone gas flow, $100 \mathrm{~L} / \mathrm{h}$; and desolvation gas flow, $1000 \mathrm{~L} / \mathrm{h}$. Low collision energy at $6 \mathrm{~V}$, high collision energy at 20-50 V, and lock mass solution at $1 \mathrm{ng} / \mu \mathrm{L}$ were used to calibrate mass accuracy. All LC-MS/MS data were processed by the MassLynx version 3.5 NT Quattro data acquisition software (Milford, MA, USA). For putative compound identification, accurate mass screening was carried out using the UNIFI data analysis software (San Mateo, CA, USA). The acquired MS spectra were subjected to library matching using the Traditional Chinese Medicine (TCM) library that is integrated within the UNIFI analysis software. Annotation of the candidate masses was based on the accurate mass match, isotopic ratio match, and precursor ion intensity counts. The criteria for a component ID to be considered a good match were as follows: a mass accuracy error $\leq 5 \mathrm{mDa}$ or $\geq-5 \mathrm{mDa}$ and a response precursor for precursor ion $\geq 2000$.

\subsection{Statistical Analysis}

All values were reported as mean values with standard deviations (mean $\pm \mathrm{SD}$ ). Statistical significance of the data was analyzed by one-way ANOVA and Levene's test followed by Tukey's honestly significant difference (HSD) test (GraphPad Prism 5 software package, version 5.02, GraphPad Software Inc., San Diego, CA, USA), and $p<0.05$ was considered statistically significant.

\section{Conclusions}

This study has demonstrated the first therapeutic potential of G. speciosa on neuroblastoma cytotoxicity, cyclooxygenase- 1 inhibition, and the control of $\mathrm{A} \beta$ aggregation. The results of the untargeted LC-MS metabolite profiling also describe several compounds, which might be pharmacologically relevant. Hence, deeper understanding of the chemistry and pharmacological aspect of $G$. speciosa is warranted as this plant is being utilized in traditional folk medicine. It also presents its significance as a prospective biologically active material for further development of novel and safer plant-based agents and/or pharmacologically relevant natural products for anti-inflammatory or anti-neurodegenerative diseases.

Author Contributions: M.A.T. and S.S.A.A. conceptualized the research and wrote the manuscript; M.A.T. and M.W.D.L. performed the experiments; G.J.D.A. collected and authenticated the plants.

Funding: This research was funded by the National Research Foundation of Korea (NRF) Grants awarded by the Korean government (MEST, No. 2017R1A2B4012636). The Philippine DOST-NSC-SEI for the thesis grant was awarded to M.W.D.L. 
Acknowledgments: The Pascual Pharma Corporation is gratefully acknowledged for the LC-MS analysis. We also thank Felicidad Christina Ramirez for the help on the statistical analyses.

Conflicts of Interest: The authors declare no conflicts of interest.

\section{References}

1. Alejandro, G.J.D. The Current Status of the Philippine Rubiaceae. Phil. J. Syst. Biol. 2007, 1, 47-60. [CrossRef]

2. Puff, C.; Chayamarit, K.; Chamchumroon, V. Rubiaceae of Thailand: A Pictorial Guide to Indigenous and Cultivated Genera; Forest Herbarium, National Park, Wildlife and Plant Conservation Department: Prachachon, Bangkok, 2005.

3. Capasso, A.; Balderrama, L.; Sivila, S.C.; De Tommasi, N.; Sorrentino, L.; Pizza, C. Phytochemical and pharmacological studies of Guettarda acreana. Planta Med. 1998, 64, 348-352. [CrossRef] [PubMed]

4. Gandhimathi, R.; Saravana, K.A.; Senthil Kumar, K.K.; Kusuma, P.K.; Uma, M.J. Pharmacological studies of anti-diarrhoeal activity of Guettarda speciosa (L.) in experimental animals. J. Pharm. Sci. Res. 2009, 2, 61-67.

5. Saravana Kumar, A.; Gandhimathi, R. Effect of Guettarda speciosa extracts on biogenic amines concentrations in rat brain after induction of seizure. Int. J. Pharm. Pharm. Sci. 2009, 1, 237-243.

6. Mohotti, S.; Rajendran, S.; Muhammad, T.; Strömstedt, A.; Adhikari, A.; Burman, R.; deSilva, E.; Göransson, U.; Hettiarachchi, C.; Gunasekera, S. Screening for bioactive metabolites in Sri Lankan medicinal plants by microfractionation and targeted isolation of antimicrobial flavonoids from Derris scandens. J. Ethnopharm. 2020, 246, 112158. [CrossRef]

7. Kaou, A.M.; Mahiou-Leddet, V.; Hutter, S.; Aïnouddine, S.; Hassani, S.; Yahaya, I.; Azas, N.; Ollivier, E. Antimalarial activity of crude extracts from nine African medicinal plants. J. Ethnopharm. 2008, 116, 74-83. [CrossRef]

8. Le, H.T.; Cho, Y.C.; Cho, S. Methanol extract of Guettarda speciosa Linn. inhibits the production of inflammatory mediators through the inactivation of Syk and JNK in macrophages. Int. J. Mol. Med. 2018, 41, 1783-1791. [CrossRef]

9. Cai, W.-H.; Matsunami, K.; Otsuka, H.; Shinzato, T.; Takeda, Y. A glycerol $\alpha$-D-glucuronide and a megastigmane glycoside from the leaves of Guettarda speciosa L. J. Nat. Med. 2011, 65, 364-369. [CrossRef]

10. Inouye, H.; Takeda, Y.; Nishimura, H.; Kanomi, A.; Okuda, T.; Puff, C. Chemotaxonomic studies of Rubiaceous plants containing iridoid glycosides. Phytochem. 1988, 27, 2591-2598. [CrossRef]

11. Mongrand, S.; Badoc, A.; Patouille, B.; Lacomblez, C.; Chavent, M.; Bessoule, J. Chemotaxonomy of the Rubiaceae family based on leaf fatty acid composition. Phytochem. 2005, 66, 549-559. [CrossRef]

12. Bagyinszky, E.; Giau, V.V.; Shim, K.; Suk, K.; An, S.S.A.; Kim, S. Role of inflammatory molecules in the Alzheimer's disease progression and diagnosis. J. Neurol. Sci. 2017, 376, 242-254. [CrossRef] [PubMed]

13. Giau, V.V.; An, S.S.A. Epitope mapping immunoassay analysis of the interaction between $\beta$-amyloid and fibrinogen. Int. J. Mol. Sci. 2019, 20, 496. [CrossRef] [PubMed]

14. Olivar, J.E.; Sy, K.; Villanueva, C.; Alejandro, G.J.; Tan, M.A. Alkaloids as chemotaxonomic markers from the Philippine endemic Uncaria perrottetii and Uncaria lanosa f. philippinensis. J. King Saud. Univ. Sci. 2018, 30, 283-285. [CrossRef]

15. Tan, M.A.; Callanta, R.B.; Apurillo, C.C.; delaCruz, T.E.; Alejandro, G.J.; Ysrael, M.C. Anti-inflammatory and antimicrobial constituents from the leaves of Villaria odorata. Acta. Manil. 2014, 62, 47-52.

16. Wu, G.-J.; Chen, W.-F.; Hung, H.-C.; Jean, Y.-H.; Sung, C.-S.; Chakraborty, C.; Lee, H.-P.; Chen, N.-F.; Wen, Z.-H. Effects of propofol on proliferation and anti-apoptosis of neuroblastoma SH-SY5Y cell line: New insights into neuroprotection. Brain Res. 2011, 1384, 42-50. [CrossRef]

17. Chen, C.-Y. TCM database in Taiwan: The world's largest traditional Chinese medicine database for drug screening in silico. Plos ONE 2011, 6, 15939. [CrossRef]

18. He, M.; Grkovic, T.; Evans, J.R.; Thornburg, C.C.; Akee, R.K.; Thompson, J.R.; Whitt, J.A.; Harris, M.J.; Loyal, J.A.; Britt, J.R.; et al. The NCI library of traditional Chinese medicinal plant extracts- Preliminary assessment of the NCI-60 activity and chemical profiling of selected species. Fitoterapia 2019, 137, 104285. [CrossRef]

19. Aquino, R.; De Simone, F.; Senatore, F.; Pizza, C. Iridoids and secoiridoids from Guettarda platypoda. Pharm. Res.Commun. 1988, 20, 105-108. [CrossRef] 
20. De Oliveira, P.R.; Testa, G.; Medina, R.P.; De Oliveira, C.M.; Kato, L.; Da Silva, C.C.; Santin, S.M. Cytotoxic activity of Guettarda pohliana Müll. Arg. (Rubiaceae). Nat. Prod. Res. 2013, 27, 1677-1681. [CrossRef]

21. Sousa, M.P.; Matos, M.E.; Machado, M.I.; Filho, R.B.; Vencato, I.; Mascarenhas, Y.P. Triterpenoids from Guettarda angelica. Phytochem. 1984, 23, 2589-2592. [CrossRef]

22. Bhattacharyya, J.; De Almeida, M. Isolation of the constituents of the root-bark of Guettarda platypoda. J. Nat. Prod. 1985, 48, 148-149. [CrossRef]

23. Matos, M.E.; Sousa, M.P.; Machado, M.L.; Filho, R.B. Quinovic acid glycosides from Guettarda angelica. Phytochem. 1986, 25, 1419-1422. [CrossRef]

24. Ferrari, F.; Messana, I.; Botta, B. Constituents of Guettarda platypoda. J. Nat. Prod. 1986, 49, $1150-1151$. [CrossRef]

25. Luijendijk, T.J.; van der Meijden, E.; Verpoorte, R. Involvement of strictosidine as a defensive chemical in Catharanthus roseus. J. Chem. Ecol. 1996, 22, 1355-1366. [CrossRef] [PubMed]

26. Han, X.-L.; Li, J.-D.; Yang, C.; Li, Z.-Y. Sweroside eradicated leukemia cells and attenuated pathogenic processes in mice by inducing apoptosis. Biomed. Pharm. 2017, 95, 477-486. [CrossRef] [PubMed]

27. Deng, S.; West, B.J.; Jarakae Jensen, C. UPLC-TOF-MS characterization and identification of bioactive iridoids in Cornus mas fruit. J. Anal. Methods Chem 2013. [CrossRef]

28. Sun, H.; Li, L.; Zhang, A.; Zhang, N.; Lu, H.; Sun, W.; Wang, X. Protective effects of sweroside on human MG-63 cells and rat osteoblast. Fitoterapia 2013, 84, 174-179. [CrossRef]

29. Wang, R.; Dong, Z.; Lan, X.; Liao, Z.; Chen, M. Sweroside alleviated LPS-induced inflammation via SIRT1 mediating NF- $\mathrm{KB}$ and FOXO1 signaling pathways in RAW 264.7 cells. Molecules 2019, 24, 872. [CrossRef]

30. Xu, Y.-D.; Sun, M.-F.; Zhu, Y.-L.; Chu, M.; Shi, Y.-W.; Lin, S.-L.; Yang, X.-S.; Shen, Y.-Q. Neuroprotective effects of loganin on MPTP-induced Parkinson's disease mice: Neurochemistry, Glial reaction and autophagy studies. J. Cell Biochem. 2017, 118, 3495-3510. [CrossRef]

31. Khan, M.; Garg, A.; Srivastava, S.K.; Darokar, M.P. Acytotoxic agent from Strychnosnux-vomica and biological evaluation of its modified analogues. Med. Chem. Res. 2012, 21, 2975-2980. [CrossRef]

32. Pina, E.M.; Araujo, F.W.; Souza, I.A.; Bastos, I.V.; Silva, T.G.; Nascimento, S.C.; Militao, G.C.; Soares, L.A.; Xavier, H.S.; Melo, S.J. Pharmacological screening and acute toxicity of bark roots of Guettarda platypoda. Rev. Bras. Farm. 2012, 22, 1315-1322. [CrossRef]

33. Gupta, M.B.; Nath, R.; Srivastava, N.; Shanker, K.; Kishor, K.; Bhargava, K.P. Anti-inflammatory and antipyretic activities of $\beta$-sitosterol. Planta Med. 1980, 39, 157-163. [CrossRef] [PubMed]

34. Villasenor, I.M.; Angelada, J.; Canlas, A.P.; Echegoyen, D. Bioactivity studies on $\beta$-sitosterol and its glucoside. Phytother. Res. 2002, 16, 417-421. [CrossRef] [PubMed]

35. Bajko, E.; Kalinowska, M.; Borowski, P.; Siergiejczyk, L.; Lewandowski, W. 5-O-Caffeoylquinicacid: A spectroscopic study and biological screening for antimicrobial activity. LWT Food Sci. Technol. 2016, 65, 471-479. [CrossRef]

36. Toyama, D.O.; Ferreira, M.; Romoff, P.; Favero, O.A.; Gaeta, H.H.; Toyama, M.H. Effect of chlorogenic acid (5-caffeoylquinic acid) isolated from Baccharis oxyodonta on the structure and pharmacological activities of secretory phospholipase A2 from Crotalus durissus terrificus. Biomed. Res. Int. 2014, 2014. [CrossRef] [PubMed]

37. Haraguchi, H.; Kataoka, S.; Okamoto, S.; Hanafi, M.; Shibata, K. Antimicrobial triterpenes from Ilex integra and the mechanism of antifungal action. Phytother. Res. 1999, 13, 151-156. [CrossRef]

38. Nguyen, H.T.; Ho, D.V.; Vo, H.Q.; Le, A.T.; Nguyen, H.M.; Kodama, T.; Ito, T.; Morita, H.; Raal, A. Antibacterial activities of chemical constituents from the aerial parts of Hedyoti spilulifera. Pharm. Biol. 2017, 55, 787-791. [CrossRef]

39. Tabassum, N.; Lee, J.H.; Yim, S.H.; Batkhuu, G.J.; Jung, D.W.; Williams, D.R. Isolation of 4,5-O-dicaffeoylquinic acid as a pigmentation inhibitor occurring in Artemisi acapillaris Thunberg and its validation in vivo. Evid. Based Complement. Altern. Med. 2016, 2016. [CrossRef]

40. Martins, D.; Nunez, C.V. Secondary metabolites from Rubiaceae species. Molecules 2015, 20, 13422-13495. [CrossRef]

41. Chadha, N.; Silakari, O. Indoles as therapeutics of interest in medicinal chemistry: Bird's eye view. Eur. J. Med. Chem. 2017, 134, 159-184. [CrossRef]

42. Viljoen, A.; Mncwangi, N.; Vermaak, I. Anti-inflammatory iridoids of botanical origin. Curr. Med. Chem. 2012, 19, 2104-2127. [CrossRef] [PubMed] 
43. Perrone, M.G.; Scilimati, A.; Simone, L.; Vitale, P. Selective COX-1 inhibition: A therapeutic target to be reconsidered. Curr. Med. Chem. 2010, 17, 3769-3805. [CrossRef] [PubMed]

44. Bjarnason, I.; Scarpignato, C.; Holmgren, E.; Olszewski, M.; Rainsford, K.D.; Lanas, A. Mechanism of damage to the gastrointestinal tract from nonsteroidal anti-inflammatory drugs. Gastroenterology 2018, 154, 500-514. [CrossRef] [PubMed]

45. Hošek, J.; Leláková, V.; Bobál, P.; Pížová, H.; Gazdová, M.; Malaník, M.; Jakubczyk, K.; Vesely, O.; Landa, P.; Temml, V.; et al. Prenylated stilbenoids affect inflammation by inhibiting the NF-KB/AP-1 signaling pathway and cyclooxygenases and lipoxygenase. J. Nat. Prod. 2019, 82, 1839-1848. [CrossRef]

46. Xia, C.-L.; Tang, G.-H.; Guo, Y.-Q.; Xu, Y.-K.; Huang, Z.-S.; Yin, S. Mulberry Diels-Alder-type adducts from Morus alba as multi-targeted agents for Alzheimer's disease. Phytochem. 2019, 157, 82-91. [CrossRef]

47. Alghazwi, M.; Smid, S.; Musgrave, I.; Zhang, W. In vitro studies of the neuroprotective activities of astaxanthin and fucoxanthin against amyloid beta $\left(\mathrm{A} \beta_{1-42}\right)$ toxicity and aggregation. Neurochem. Int. 2019, 124, $215-224$. [CrossRef]

48. Tran, A.V.; Shim, K.H.; Vo Thi, T.T.; Kook, J.K.; An, S.S.A.; Lee, S.W. Targetted and controlled drug delivery by multifunctional mesoporous silica nanoparticles with internal fluorescent conjugates and external polydopamine and graphene oxide layers. Acta. Biomater. 2018, 74, 397-413. [CrossRef]

Sample Availability: Samples of the plant extracts are available from the authors. 